\title{
Labile complexes facilitate cadmium uptake by Caco-2 cells
}

L. Verheyen ${ }^{1 *}$, F. Degryse ${ }^{1 \dagger}$, T. Niewold ${ }^{2}$ and E. Smolders ${ }^{1}$

${ }^{1}$ Division of Soil and Water Management, K.U.Leuven, Kasteelpark Arenberg 20 - box 2459, 3001 Heverlee, Belgium.Liesbeth.Verheyen@ees.kuleuven.be

${ }^{2}$ Division Animal-nutrition-quality, K.U.Leuven, Kasteelpark Arenberg 30 - box 2456, 3001 Heverlee, Belgium.

${ }^{\dagger}$ Current address: School of Agriculture, Food \& Wine, The University of Adelaide, SA 5005, Australia

*Corresponding author: Tel.: +32163216 30, fax: +32 16321997

E-mail address: Liesbeth.Verheyen@ees.kuleuven.be 


\begin{abstract}
The Free Ion Activity Model (FIAM) predicts that metal uptake in biota is related to the free ion activity in the external solution and that metal complexes do not contribute. However, studies with plants have shown that labile metal complexes enhance metal bioavailability when the uptake is rate-limited by transport of the free ion in solution to the uptake site. Here, the role of labile complexes of $\mathrm{Cd}$ on metal bioavailability was assessed using Caco- 2 cells, the cell model for intestinal absorption. At low $\mathrm{Cd}^{2+}$ concentration $(1 \mathrm{nM})$, the $\mathrm{CdCl}_{n}{ }^{2-n}$ complexes contributed to the uptake almost to the same extent as the free ion. At large $\mathrm{Cd}^{2+}$ concentration $(10 \mu \mathrm{M})$, the contribution of the complexes was much smaller. At constant $\mathrm{Cd}^{2+}$ concentration, $\mathrm{Cd}$ intake in the cells from solutions containing synthetic ligands such as EDTA increased as the dissociation rate of the cadmium complexes increased, and correlated well with the $\mathrm{Cd}$ diffusion flux in solution measured with the Diffusive Gradient in Thin Films technique (DGT). The Cd intake fluxes in the cells were well predicted assuming that the specific uptake is limited by diffusion of the free $\mathrm{Cd}^{2+}$ ion to the cell surface. Our results underline that speciation of $\mathrm{Cd}$ has a major effect on its uptake by intestinal cells, but the availability is not simply related to the free ion concentration. Labile complexes of Cd enhance metal bioavailability in these cells, likely by alleviating diffusive limitations.
\end{abstract}

Key Words: metal uptake; speciation; FIAM; complexes; Caco-2 cells 


\section{Introduction}

Cadmium $(\mathrm{Cd})$ is a non-essential metal of concern in the human food chain. Food is a major source of $\mathrm{Cd}$ in the non-smoking population. The gastrointestinal absorption of $\mathrm{Cd}$ from ingested food, dust or soil is largely affected by the metal speciation in the matrix and by ionic interactions during uptake by intestinal cells. Studies in rats, for example, illustrate that $\mathrm{Cd}$ absorption increases when lowering iron (Fe) and zinc (Zn) supply (Reeves and Chaney, 2001b). Knowledge of the factors affecting the metal bioavailability is necessary for human health risk assessment of toxic trace metals such as $\mathrm{Cd}$ and is also required to understand micronutrient deficiency in humans (Hotz, 2005; Ryan et al., 2004; Simon-Hettich et al., 2001; Vahter et al., 1996). The Caco-2 cell line, a human colon carcinoma (Fogh et al., 1977), is a well established cell model for intestinal absorption. These enterocyte-like cells with the functional properties of transporting epithelia are cultured on a porous membrane and form a dense monolayer. The Caco- 2 cell line has been used since 1980 to study the absorption of drugs (Artursson et al., 2001) and is increasingly used to identify mechanisms of trace metal absorption (e.g. Elisma and Jumarie, 2001; Pigman et al., 1997; Reeves et al., 2001a; Hotz, 2005). The model is considered as a relevant in vitro model for studying both the passive and mediated intestinal absorption of metals such as Cd and Zn (Jumarie et al., 2001; Seiquer et al., 2000). The in vitro model systems demonstrate that complexation of metals with organic ligands such as phytate and casein reduce Zn availability (Han et al., 1994; Navarro et al., 2000), confirming human nutritional studies (Turnlund et al., 1984; Lönnerdal et al., 1984). Jumarie et al. (2001) and Elisma and Jumarie (2001) showed that the uptake rate of the Cd by Caco- 2 cells was affected by speciation of the metals in solution. Moreover, their study revealed that $\mathrm{Cd}$ uptake is not simply related to the concentration of the free metal ion, indicating that the free ion activity model (FIAM) for 
bioavailability (Morel, 1983) is not always valid in this system. For example, the uptake of Cd by the cells was larger in the presence of Cd-chloride complexes $\left(\mathrm{CdCl}_{n}{ }^{2-n}\right)$ than in the absence of complexes at the same free $\mathrm{Cd}^{2+}$ concentration (Jumarie et al., 2001). Similar observations were made for complexes of $\mathrm{Cd}$ with glutathione or phytochelatin. This was attributed to direct uptake of complexes, however no direct evidence was provided (Jumarie et al. 2001).

Alternatively, we propose that the contribution of metal complexes to uptake might be related to their effect on metal diffusion through an unstirred layer from the solution to the cells. Diffusion can be the rate limiting mechanism in the uptake process when the potential internalization rate is larger than the maximal rate of diffusion to the membrane. When the free metal ion at the membrane is depleted from the bulk solution, complexes may enhance the metal diffusion flux through solution because they dissociate within the diffusion layer. The increased diffusion leads to larger free ion concentrations at the uptake site and, hence, larger uptake. The contribution of the complexes to the uptake therefore increases as the concentration and the dissociation rate of the complex increases, as was shown for Cd uptake by plants (Degryse et al., 2006a). Diffusive limitation for Cd uptake might occur in the Caco-2 cell line and, potentially, also in vivo where a mucus layer can impose an even larger diffusive barrier than in the mucus-free Caco-2 cell model. The permeability coefficient (i.e. the flux to metal concentration ratio) of different drugs in the Caco-2 cells can reach values in the order of $5 \times 10^{-5} \mathrm{~cm} / \mathrm{s}$ (Karlsson and Artursson, 1991). Also for Cd, permeability coefficients in this order of magnitude have been observed (Duizer et al., 1999). Such high permeability coefficients are close to theoretical maximal values when diffusion through an unstirred layer above the Caco-2 cell monolayer limits uptake (Karlsson and Artursson, 1991). No differences in Cd uptake by Caco-2 cells were found between swirled and unswirled systems (Jumarie et al. 1997), suggesting that no mass transfer limitation were present. 
However, swirling does not completely remove an unstirred layer. Moreover, a relatively large solution concentration of $0.3 \mu \mathrm{M} \mathrm{Cd}$ was used in that study.

The goal of this study is to investigate the role of complexes on uptake of $\mathrm{Cd}$ by Caco- 2 cells and test the hypothesis that uptake may be under diffusion control. This is assessed by exposing the cells to metal complexes varying in dissociation rate at different concentrations of $\mathrm{Cd}^{2+}$ or $\mathrm{Zn}^{2+}$. At large metal ion concentrations, the metal internalization saturates and diffusion limitations are less likely than at lower concentration. The maximal diffusion flux of metals in the same test solutions was measured under zero sink conditions using the Diffusive Gradient in Thin Film (DGT) technique. Zinc was included in these studies as it is the nutritional analogue of $\mathrm{Cd}$ and because Cd:Zn interactions may take place during uptake.

\section{Materials and Methods}

\subsection{Cell culture}

The human colon adenocarcinoma Caco-2 cell line (obtained from ATCC, American Type culture Collection) was grown up in a Minimum Essential Medium with Earle's salts (MEM) at $37^{\circ} \mathrm{C}$ and $5 \% \mathrm{CO}_{2}$ in air. The MEM solution contains $2 \mathrm{mM} \mathrm{L}$-glutamine, $0.24 \mathrm{mM} \mathrm{NaHCO} 3,0.1$ $\mathrm{mM}$ non-essential amino acids, $0.8 \mathrm{mM}$ Na-pyruvate, $20 \%$ foetal bovine serum and $1 \%$ penicillin/streptomycin solution. The culture medium was changed every 2 days. The cells were passaged by trypsinisation at a stage of almost completely confluence.

Cells (passage 5-7) were seeded on permeable filters (pore size: $0.4 \mu \mathrm{m}$, surface: $1.12 \mathrm{~cm}^{2}$, polyester ore collagen coated polytetrafluoroethelene (PTFE)) with a density of $4.5 \times 10^{5}$ cells $/ \mathrm{cm}^{2}$. The cells were used at day 14 (collagen coated PTFE filter) or at day 21 (polyester 
filter) after seeding. The cell monolayer integrity was checked by measuring the transepithelial electrical resistance (TEER) (Hidalgo et al., 1989). The TEER was between 230 and $390 \Omega . \mathrm{cm}^{2}$ (polyester filter) or between 200 and $310 \Omega \cdot \mathrm{cm}^{2}$ (collagen coated PTFE filter), indicating that a monolayer was formed (Irvine et al., 1999; Ingels et al., 2002).

\subsection{Uptake-transport experiments}

Uptake of $\mathrm{Cd}$ and $\mathrm{Zn}$ from apical solution and transport from apical to basolateral site was determined using ${ }^{109} \mathrm{Cd}$ and ${ }^{65} \mathrm{Zn}$ spiked apical solutions (see below: test solutions). Metal uptake was measured from the loss of radioactivity in the apical solution. Metal transport to the basolateral side was measured from the increase in radioactivity at the basolateral side. Metal retained in the cells (= intake) was calculated from the activity in the cells at the end of the experiments ( $6 \mathrm{~h}$ or $4 \mathrm{~h}$, see below). The radioactivity was converted to molar units of $\mathrm{Cd}$ and $\mathrm{Zn}$ based on the specific activity (radioactivity relative to stable concentration) of $\mathrm{Cd}$ and $\mathrm{Zn}$ in the test solution. The amount of metal taken up (calculated from the loss from the apical side) was within $5 \%$ of the summed amounts of metal retained in the cell, metal transported to the basolateral side and metal in the desorption solution, indicating good analytical accuracy. For strongly buffered solutions, the decrease in activity at the apical side was very small. Therefore, uptake was calculated based on metal recovered in the basolateral compartment (= transport) and in the cells (= intake) (Figure 1$)$.

All experiments were performed in a water bath at $37^{\circ} \mathrm{C}$ with duplicate wells per treatment (see below). The cells were rinsed twice with the test solutions at the apical side $(0.5 \mathrm{ml})$ and with the basal medium at the basolateral side $(1.5 \mathrm{ml})$ before starting the test. This basal medium contained $137 \mathrm{mM} \mathrm{NaNO}_{3}, 5 \mathrm{mM} \mathrm{KNO}_{3}, 1.2 \mathrm{mM} \mathrm{Ca}\left(\mathrm{NO}_{3}\right)_{2}, 4 \mathrm{mM}$ D-glucose and $10 \mathrm{mM}$ 
HEPES $(\mathrm{pH}=7.2)$. The test started after adding $0.5 \mathrm{ml}$ of preheated $\left(37^{\circ} \mathrm{C}\right)$ test solution at the apical side and $1.5 \mathrm{ml}$ preheated basal medium at the basolateral side. Every hour, solution was sampled at the apical side $(0.4 \mathrm{~mL})$ and at the basolateral side $(1 \mathrm{~mL})$ and the sampled solutions were replaced with fresh media. At the last sampling occasion (6 or 4 hours), the remaining solution was removed and ice-cold desorption solution was added at both sides of the cells, to remove metals adsorbed on the cell surface. The desorption solution contained $150 \mathrm{mM} \mathrm{NaCl}, 10$ mM HEPES $(\mathrm{pH}=7.2)$ and $1 \mathrm{mM}$ EDTA. The concentration of ${ }^{109} \mathrm{Cd}$ and ${ }^{65} \mathrm{Zn}$ in the cells, and in the apical, basolateral and desorption solutions was measured with a gamma-counter (Minaxi 5000 autogamma).

\subsection{Test solutions}

All test solutions were labeled with ${ }^{109} \mathrm{Cd}(\sim 40 \mathrm{kBq} / \mathrm{L}$, Perkin Elmer $)$ and ${ }^{65} \mathrm{Zn}(\sim 160 \mathrm{kBq} / \mathrm{L}$, Perkin Elmer) 24 hours before the beginning of the test. These apical solutions had the same basal composition as the medium used at the basolateral side. Each treatment was made in duplicate. One well in each 12-well plate was used as a control. The nitrate solution consisted of the basal medium labeled with carrier-free ${ }^{109} \mathrm{Cd}$ and ${ }^{65} \mathrm{Zn}$, in which $\mathrm{Cd}$ and $\mathrm{Zn}$ are mainly present as free cation (see further). In each plate, there was one well without cells for which the same solution was used.

Solutions with varying metal concentration. The influence of time and concentration on the uptake and transport of $\mathrm{Cd}$ and $\mathrm{Zn}$ by Caco- 2 cells was assessed using apical solutions (basal medium) with varying $\mathrm{Cd}$ and $\mathrm{Zn}$ concentrations, to assess at which concentration the uptake saturates, and thus identify the concentration ranges for which diffusive limitations are more or less likely. The $\mathrm{Cd}$ and $\mathrm{Zn}$ concentrations were covaried (molar $\mathrm{Zn}: \mathrm{Cd}$ ratio 10), and were 0.001, 
1 and $10 \mu \mathrm{M}$ for $\mathrm{Cd}$ and $0.01 \mu \mathrm{M}, 10$ and $100 \mu \mathrm{M}$ for $\mathrm{Zn}$. A few solutions contained only $\mathrm{Cd}(1$, $10,30 \mu \mathrm{M})$ and carrier-free ${ }^{65} \mathrm{Zn}$, or only $\mathrm{Zn}(100 \mu \mathrm{M})$ and carrier-free ${ }^{109} \mathrm{Cd}$ (Table 1). This design allowed for assessing $\mathrm{Cd}-\mathrm{Zn}$ interactions on uptake in these cells.

Chloride versus nitrate solutions. The influence of the presence of $\mathrm{CdCl}_{n}^{2-n}$ complexes on the $\mathrm{Cd}$ uptake by Caco- 2 cells was investigated by comparing uptake from solutions with $\mathrm{NaCl}$ or $\mathrm{NaNO}_{3}$ for different $\mathrm{Cd}^{2+}$ concentrations. In the $\mathrm{NaCl}$ solutions, $\mathrm{NaNO}_{3}$ in the basal medium was substituted for $\mathrm{NaCl}$. The $\mathrm{NaNO}_{3}$ treatments served as a control solution since Cd is mainly (88\%) present as free ion in the basal medium. In the solution with $137 \mathrm{mM} \mathrm{NaCl}$, only a fraction of $\mathrm{Cd}$ is present as free ion, because of the formation of a complex with chloride (Table 2). The uptake experiments with $\mathrm{NaNO}_{3}$ were carried out for three Cd levels: a free $\mathrm{Cd}^{2+}$ activity of $10^{-9.5}$ $\mathrm{M}$ (i.e. $\mathrm{pCd}=-\log$ free $\mathrm{Cd}^{2+}$ activity $\left.=9.5\right), 10^{-7.5} \mathrm{M}(\mathrm{pCd} 7.5)$ or $10^{-5.5} \mathrm{M}(\mathrm{pCd} 5.5)$. Speciation calculations (GEOCHEM-PC, Parker et al., 1995) were used to calculate the total dissolved Cd concentrations required to obtain the same free $\mathrm{Cd}^{2+}$ concentration as in the $\mathrm{NaNO}_{3}$ solutions (Table 2). Speciation measurements on these solutions were performed (see below) to verify the predicted speciation because no complexation constants are available for complex formation between Cd and HEPES. At the ionic strength of the uptake medium (at which the activity coefficient of a divalent ion is 0.33 ), the free ion concentration is 3 -fold larger than the free ion activity. Thus, total $\mathrm{Cd}$ concentrations were $0.001,0.1$ and $10 \mu \mathrm{M}$ for the $\mathrm{NaNO}_{3}$ treatments and $0.006,0.6$ and $60 \mu \mathrm{M}$ for the $\mathrm{NaCl}$ treatments. The total zinc concentrations were $0.01,1$ and 100 $\mu \mathrm{M}$ (or pZn 8.6, 6.6 and 4.6) for the low, medium and high Cd level respectively.

Solutions with synthetic ligands. The effect of various complexes with different dissociation rates was assessed using solutions with synthetic ligands: HEDTA (N-(2hydroxyethyl)ethylenediamine-N,N',N'-triacetate), EDTA (ethylenediaminetetraacetate) or 
CDTA (trans-1,2-cyclohexyldiamine-N,N,N',N'-tetraacetate). These ligands were chosen because their complexes with $\mathrm{Cd}$ cover a wide range in dissociation rate and they are not likely to be transported through the cell membrane (Degryse et al., 2006b). The solutions were made by adding $1 \mu \mathrm{M}$ total $\mathrm{Cd}$ to the basal medium and ligand in the concentration needed to obtain the desired degree of complexation resulting in a free $\mathrm{Cd}^{2+}$ concentration of $1 \mathrm{nM}$ (or pCd 9.5). These ligand concentrations were calculated from the nominal total solution composition (i.e. including $\mathrm{Ca}$, Na etc.) with GEOCHEM-PC (Parker et al., 1995), and were $3.5 \mu \mathrm{M}$ for HEDTA, $4.8 \mu \mathrm{M}$ for EDTA and $1.5 \mu \mathrm{M}$ for CDTA.

The speciation in the solutions described above relies on speciation calculations. Uncertainty in the complexation constants may result in wrongly estimated free $\mathrm{Cd}^{2+}$ concentration. Therefore, an additional experiment was carried out using Chelex ${ }^{\circledR}-100$ resin (Bio-rad; 0.62 mmol $_{\mathrm{c}} /(\mathrm{g}$ wet weight)), a metal-selective resin, to buffer the metal activities. Solutions were made with $10 \mu \mathrm{M}$ NTA, $0.2 \mu \mathrm{M}$ HEDTA, $1 \mu \mathrm{M}$ EDTA and $1 \mu \mathrm{M}$ CDTA. These solutions were equilibrated with a Chelex resin that was loaded with metals $(\mathrm{Zn} / \mathrm{Ca} / \mathrm{Cu} / \mathrm{Cd}: 0.80 / 0.13 / 0.05 / 0.02$; methodological details given by Degryse et al., 2006b), to obtain a constant free ion concentration of $\mathrm{Cd}^{2+}(\mathrm{pCd}$ 8.7) and $\mathrm{Zn}^{2+}(\mathrm{pZn} 7.8)$ in each solution.

\subsection{Speciation measurements}

The Donnan membrane equilibrium technique (Helmke et al., 1999) was used to measure the free ion fraction of $\mathrm{Cd}$ in the solutions with either $137 \mathrm{mM} \mathrm{NaNO}_{3}$ or $\mathrm{NaCl}$. This allowed assessing whether there was no complexation of Cd with the $\mathrm{pH}$ buffer (HEPES) and whether the predicted complexation of $\mathrm{Cd}$ with chloride was accurate. The Donnan method uses a cation exchange 
membrane (Nafion-117) separating the donor solution (i.e. test solution) from a small volume of acceptor solution. The acceptor solution contains initially no $\mathrm{Cd}$ and, has the same ionic strength as the donor solution. The free metal cation is able to migrate through the membrane while the neutral or anionic ligands or metal complexes are virtually excluded. At equilibrium, the free metal ion concentration is the same at both sides if the ionic strength is the same in donor and acceptor solution (Nolan et al., 2003). Here, about $60 \mathrm{~mL}$ of donor solution was equilibrated for 2 h against $0.5 \mathrm{~mL}$ of duplicate acceptor solutions containing $155 \mathrm{mM} \mathrm{NaNO}$. The donor solutions were the test solutions used in the nitrate versus chloride experiment described above at carrierfree $\mathrm{Cd}$. The donor solution was labeled with ${ }^{109} \mathrm{Cd}(\sim 34 \mathrm{kBq} / \mathrm{L}$, Perkin Elmer $)$ and solution activities were measured in $0.4 \mathrm{~mL}$ samples with the gamma counter. GEOCHEM-PC predicts that about $10 \%$ of $\mathrm{Cd}$ is complexed by $\mathrm{NO}_{3}{ }^{-}$in the acceptor and, logically, this complexation cannot be detected as it occurs to almost the same extent in the donor solution (which contained $155 \mathrm{mM} \mathrm{NO}_{3}{ }^{-}$). Nitrate was deliberately chosen as the anion in the acceptor solution to verify the lack of complexation of $\mathrm{Cd}$ with HEPES and to verify $\mathrm{Cd}$ complexation in chloride solutions relative to that in the nitrate solutions.

\subsection{Diffusive Gradients in Thin Films (DGT)}

The Diffusive Gradient in thin film (DGT) technique (Zhang and Davison, 2000) was used to measure the zero sink diffusion flux of $\mathrm{Cd}$ and $\mathrm{Zn}$ in the test solutions with synthetic ligands (without Chelex equilibration). This technique gives an indication of the order of contribution of the complexes to the diffusion flux. Slowly dissociating complexes have less contribution to the diffusion flux than fast dissociating complexes. The DGT device (DGT Research, Lancaster, UK) 
consists of two gel layers and a filter membrane enclosed in a plastic holder with a window (Figure 2). The resin gel layer contains the binding agent Chelex that acts as a zero sink for trace metals and induces a diffusion flux of the metals from the solution to the resin gel layer. The resin is assumed to bind exclusively with the free metal ion. The resin layer is overlaid by a porous hydrogel layer (diffusion layer, $0.76 \mathrm{~mm}$ ) and by a filter membrane (with a $0.45-\mu \mathrm{m}$ pore size, $0.14 \mathrm{~mm}$ ). Ions can freely diffuse through the diffusion layer to the resin layer. The DGT measurements in solution are carried out by exposing the DGT device for a given 'deployment time' (here 24 hours) to a stirred solution $\left(100 \mathrm{~mL}, 20^{\circ} \mathrm{C}\right)$. During deployment, a steady state is achieved after 5 minutes of exposure. Once steady-state is reached, the amount of metal sorbed on the Chelex increases linear with time.

The solution with DGT device was placed on a horizontal shaker during the deployment. The resin gel was retrieved and eluted with $1 \mathrm{~mL}$ of $1 \mathrm{M} \mathrm{HNO}_{3}$. The radioactivity in the eluant was determined and converted to stable $\mathrm{Cd}$ and $\mathrm{Zn}$ concentrations based on the specific activity of the test solutions. The DGT measured flux, $F_{\text {DGT }}$, was calculated as:

$F_{\text {DGT }}=\frac{M}{A . t}$

where $M$ is the amount of metal accumulated on the resin, $A$ is the surface area (window area: $3.14 \mathrm{~cm}^{2}$ ) and $t$ is the deployment time.

\subsection{Statistical analysis}

Two sided t-tests assuming equal variances were used to identify statistically significant treatment effects at $\alpha=0.05$. 


\section{Results}

\subsection{Uptake and transport as function of time and metal concentration}

The uptake of $\mathrm{Cd}$ and $\mathrm{Zn}$ by the Caco- 2 cells was linear in time during the first 3 hours for the two treatments with the lowest metal concentrations $(0.001 \mu \mathrm{M} \mathrm{Cd}$ and $0.01 \mu \mathrm{M} \mathrm{Zn}$, or $0.1 \mu \mathrm{M}$ $\mathrm{Cd}$ and $1 \mu \mathrm{M} \mathrm{Zn}$ ) (Figure 3a). After the first 3 hours, the uptake of the metals reached equilibrium. In the treatment with the highest metal concentrations $(10 \mu \mathrm{M} \mathrm{Cd}$ and $100 \mu \mathrm{M} \mathrm{Zn})$, the uptake rate of $\mathrm{Cd}$ and $\mathrm{Zn}$ increased after 2 hours (Figure 3b), suggesting that the high metal levels damaged the cells. Single dosing experiments with $\mathrm{Cd}^{2+}$ or $\mathrm{Zn}^{2+}$ salts showed that these effects were related to the large $\mathrm{Cd}$ and not $\mathrm{Zn}$ concentration. For this reason, the uptake flux of $\mathrm{Cd}\left(F_{\text {uptake }}\right)$ was derived based on the first hour:

$$
F_{\text {uptake }}=\frac{M}{A . t}
$$

where $M$ is the amount of $\mathrm{Cd}$ taken up by the cells (calculated from the decrease in radioactivity in the apical solution) after one hour, $A$ the uptake surface area $\left(1.12 \mathrm{~cm}^{2}\right)$ and $t$ the exposure time.

The permeability $P(\mathrm{~cm} / \mathrm{s})$, which is often used to express the transport of compounds across cells, was calculated as the ratio of the flux $\left(\mathrm{nmol} / \mathrm{cm}^{2} / \mathrm{s}\right)$ and the concentration $\left(\mathrm{nmol} / \mathrm{cm}^{3}\right)$ :

$$
P=\frac{F}{c}
$$

The permeability was between $15.6 \times 10^{-6}$ and $44.7 \times 10^{-6} \mathrm{~cm} / \mathrm{s}$ for $\mathrm{Cd}$, and between $11.1 \times 10^{-6}$ and $59.5 \times 10^{-6} \mathrm{~cm} / \mathrm{s}$ for $\mathrm{Zn}$ (Table 1). Figure 4 shows the permeabilities and uptake fluxes as function of the free ion concentration, illustrating the saturation in the uptake at the highest metal 
concentrations. The experiments with altered $\mathrm{Cd}: \mathrm{Zn}$ concentration ratios in solution revealed no significant or large Cd:Zn interactions on Cd or on Zn uptake (Table 1).

For the well without cells, the permeability was $71 \times 10^{-6} \mathrm{~cm} / \mathrm{s}$ for $\mathrm{Cd}$ and $75 \times 10^{-6} \mathrm{~cm} / \mathrm{s}$ for $\mathrm{Zn}$. The fact that the permeabilities for the Caco-2 cells at the low metal activities is of the same order as that for the well without cells (only diffusion) is a first indication that the uptake may be diffusion limited.

No transport of $\mathrm{Cd}$ to the basolateral side was observed at the lowest $\mathrm{Cd}$ concentration (Figure 3a). Higher concentrations of $\mathrm{Cd}$ and $\mathrm{Zn}$ in the apical solution increased transport of these metals to the basolateral side (Table 1). This indicates that either more metal taken up by the cells is excreted at the basolateral side (transcellular route) or that, at higher concentrations, relatively more metal is transported through pore junctions (paracellular route) compared to the transcellular transport (Figure 1).

\subsection{Effect of metal speciation: chloride complexes}

For zinc, the uptake was similar in both treatments (nitrate and chloride) for the two lowest metal levels after one hour of exposure (Figure 5a and b). The t-test indicated no significant difference in $\mathrm{Zn}$ uptake $(\mathrm{p}>0.05)$ between the chloride and nitrate treatments. This was expected given the similar speciation of $\mathrm{Zn}$ in the two treatments (Table 2). At the highest metal level (Figure 5c), the abrupt increase in the uptake after two hours, likely related to damage of the cell walls because of the large $\mathrm{Cd}$ concentrations, occurred earlier in the chloride treatment. The uptake of $\mathrm{Zn}$ was not significantly different $(\mathrm{p}>0.05)$ between nitrate and chloride treatment if only the linear uptake is taken into account. 
Donnan membrane equilibration of the nitrate test solution against $\mathrm{NaNO}_{3}$ in the acceptor solution yielded an acceptor:donor $\mathrm{Cd}$ concentration ratio of $1.10 \pm 0.05$ (standard deviation, $\mathrm{n}=2$ ). This means that complexation of $\mathrm{Cd}$ at trace $\mathrm{Cd}$ concentrations with HEPES is negligible because that would lower that ratio to below 1.0. The acceptor:donor $\mathrm{Cd}$ concentration ratio in the $\mathrm{NaCl}$ solution was $0.27 \pm 0.01$ (standard deviation, $\mathrm{n}=2$ ), clearly illustrating the chloride complexation of Cd. After correction for the small complexation of $\mathrm{Cd}^{2+}$ by $\mathrm{NO}_{3}^{-}$(Table 2), these measured speciation data show that the ratio of free $\mathrm{Cd}^{2+}$ fractions between the chloride and nitrate test solution is $0.21 \pm 0.01$, i.e. close to the predicted value of 0.17 (Table 2). The nitrate and chloride test solution were prepared to contain equal $\mathrm{Cd}^{2+}$ based on GEOCHEM-PC modeling, but these speciation measurements indicate that the free $\mathrm{Cd}^{2+}$ concentration may have been $25 \%$ larger in the chloride than in the nitrate solutions. The uptake of $\mathrm{Cd}$ was almost 6 times larger in the chloride treatment at $\mathrm{pCd}=9.5$ than in the nitrate treatment at the same free $\mathrm{Cd}^{2+}$ concentration (Figure 5a). This factor 6 is about equal to the ratio of the total $\mathrm{Cd}$ concentrations between the chloride and nitrate solution. Thus, even taking into account the uncertainty on the free $\mathrm{Cd}^{2+}$ concentration, our results clearly indicate that the $\mathrm{CdCl}_{n}^{2-n}$ complexes contribute to the $\mathrm{Cd}$ uptake, and that the FIAM does not hold. The difference in Cd uptake between chloride and nitrate treatments was statistically significant at all Cd activities, but the relative effects were smaller at $\mathrm{pCd}=7.5$ (factor 4) and at $\mathrm{pCd}=5.5$ (factor 1.7). The contribution $\xi$ of the Cd-chloride complexes to the uptake - relative to that of the free ion - can be calculated from (Degryse et al., 2006a):

$\frac{F_{+\mathrm{L}}}{F_{-\mathrm{L}}}=\frac{\left[\mathrm{Cd}^{2+}\right]+\xi \cdot[\mathrm{CdL}]}{\left[\mathrm{Cd}^{2+}\right]}$, or 
$\xi=\left(\frac{F_{+\mathrm{L}}}{F_{-\mathrm{L}}}-1\right) \cdot \frac{\left[\mathrm{Cd}^{2+}\right]}{[\mathrm{CdL}]}$

where $F_{+\mathrm{L}}$ and $F_{-\mathrm{L}}$ are the uptake fluxes in the solution with $\mathrm{Cd}$ complexes $(\mathrm{NaCl})$ and without $\mathrm{Cd}$ complexes $\left(\mathrm{NaNO}_{3}\right)$ at the same free $\mathrm{Cd}^{2+}$ concentration, $\left[\mathrm{Cd}^{2+}\right]$ is the concentration of the free ion and $[\mathrm{CdL}]$ the concentration of the complex. A $\xi$ value of 1 indicates that the complexes contribute equally to uptake as the free $\mathrm{Cd}^{2+}$ ion; a value of 0 indicates that the complexes do not contribute to the metal uptake. The average $\xi$ value ( \pm standard deviation) was $0.74( \pm 0.19)$ at $\mathrm{pCd} 9.5,0.54( \pm 0.14)$ at $\mathrm{pCd}=7.5$ and $0.14( \pm 0.10)$ at $\mathrm{pCd}=5.5$. The standard deviation of $\xi$ was calculated from the standard deviation of $F_{+\mathrm{L}}$ and $F_{-\mathrm{L}}$ assuming independent measurements. While a $\xi$ value $>0$ points to contribution of complexes to the uptake, it does not give information about the exact mechanism, i.e. whether complexes contribute through direct uptake or because they alleviate diffusion limitations.

\subsection{Effects of speciation: synthetic ligands}

The uptake in solutions with synthetic ligands was assessed using solutions with the same free $\mathrm{Cd}^{2+}$ concentration $(1 \mathrm{nM} ; \mathrm{pCd} 9.5)$ and the same total Cd concentration $(1 \mu \mathrm{M})$ but different ligands. Because of the buffering, the decrease in concentration at the apical side was very small, resulting in large uncertainty if uptake was calculated based on the loss of concentration in the apical side. Therefore, the uptake was calculated based on metal recovered in the cells and in the basolateral compartment after 4 hours of exposure. The uptake of $\mathrm{Cd}$ was almost the same for all treatments (Figure 6, open symbols). Most Cd was recovered in the basolateral compartment, while only a minor fraction (8-25\%) was recovered in the cells. 
If only the intake flux was considered (i.e. flux based on the amount of metal in the cell, not considering the metal in the basolateral side), there was a clear difference between treatments, with the intake flux following the order: HEDTA> EDTA>CDTA. The intake flux increased with increasing dissociation rate of the complex (Table 3) and followed the same order as the DGT flux (Figure 6, closed symbols).

The fact that there are clear treatment effects for the metal retained in the cells, but not for the metal flux to the basolateral side, suggests that the flux to the basolateral side was related to transport of the complexes through cell pore junctions (paracellular pathway), without actual uptake into the cells. This pathway likely has a large contribution for these treatments because of the large ratio of complex to free ion in the solutions (concentration ratio of 1000). Under these conditions, the transcellular permeability is small (see further), resulting in a relative larger importance of the paracellular permeability. Permeabilities were therefore both calculated for the metal retained in the cell $\left(P_{\text {cell }}\right)$ and the metal transported to the basolateral side $\left(P_{\text {baso, }}\right)$ (Table 3$)$. The former is expected to correspond approximately to the transcellular permeability, since transport from the cell into the basolateral side is expected to be small at this low $\mathrm{Cd}^{2+}$ concentration. The latter is assumed to correspond to the paracellular permeability.

The speciation in these solutions was calculated using the speciation program GEOCHEM-PC (Parker et al., 1995). The complexation constants in the database correspond to the NIST values. Nevertheless, uncertainty in the complexation constants may result in uncertainty in the free ion concentrations, which might hamper the interpretation. Therefore, an additional experiment was carried out with synthetic ligands using Chelex to buffer the free ion activities (pCd 8.7 and pZn 7.8). A control solution or nitrate solution (no added ligands, basal medium only) was included. Even though the free ion concentration was the same in all solutions, uptake in the solutions with 
complexes was 4- to7-fold larger than in the nitrate solution for $\mathrm{Cd}$ and 3- to 14-fold for $\mathrm{Zn}$

(Table 4), clearly illustrating that the FIAM is not valid and that complexes also contribute to the uptake. In this experiment, the total Cd concentration was not constant for all ligands, which complicates the interpretation, since both the concentration and dissociation rate of the complexes affect the uptake. Still, the results of this experiment confirmed the trends observed in the experiment described above. For instance, the uptake of $\mathrm{Cd}$ and $\mathrm{Zn}$ by the cells was lower for the CDTA than for the EDTA treatment, even though the total metal concentrations were larger for the CDTA treatment.

\section{Discussion}

\subsection{Time and concentration dependency}

The time and concentration results for $\mathrm{Cd}$ and $\mathrm{Zn}$ were similar both at low and high concentrations.). Cadmium and $\mathrm{Zn}$ are chemical analogues and may be taken in via the same transporters. The 10 times higher uptake and transport for $\mathrm{Zn}$ than for $\mathrm{Cd}$ was a result of the 10 times higher $\mathrm{Zn}$ than $\mathrm{Cd}$ concentration. The results obtained are in agreement with previous studies where the uptake of $\mathrm{Cd}$ and $\mathrm{Zn}$ was tested in a test solution without ligands or with 137 $\mathrm{mM} \mathrm{NaCl}$ instead of $\mathrm{NaNO}_{3}$. The uptake of $\mathrm{Cd}$ and $\mathrm{Zn}$ by the Caco- 2 cells reached equilibrium in time (Figure 3a), as also observed by Reeves et al. (2001a). The uptake increased proportionally with the $\mathrm{Cd}$ and $\mathrm{Zn}$ concentration in the apical solution at the low metal concentrations, but at larger metal concentrations, the uptake increased less than proportionally, resulting in a decrease in permeability (Figure 4), in agreement with other studies (Blais et al., 1999; Jumarie et al., 1999). At large metal concentrations, relatively more metal was transported to the basolateral side, consistent with the results of Blais et al. (1999). 
At the largest metal concentrations ( $10 \mu \mathrm{M} \mathrm{Cd}, 100 \mu \mathrm{M} \mathrm{Zn})$, a sudden increase in the uptake flux was observed between 3 and 4 hours after the start of the exposure. Uptake experiments in solutions with only $\mathrm{Cd}$ or $\mathrm{Zn}$ indicated that this effect was related to the large $\mathrm{Cd}$ concentration. The large $\mathrm{Cd}$ concentrations likely damaged the monolayer. Therefore, the metal $\mathrm{Cd}$ was able to cross the cells more readily to the basolateral side, thus increasing the uptake. Rossi et al. (1996) did also not observe toxic effects at this $\mathrm{Zn}$ concentration; a decrease in the TEER value only occurred at $\mathrm{Zn}$ concentrations above $500 \mu \mathrm{M}$. Most likely, the increase in the uptake flux resulted from Cd induced damage of the cells. Duizer et al. (1999) showed disruption of the junctional barrier at a Cd concentration above $25 \mu \mathrm{M}$ and a calculated free $\mathrm{Cd}^{2+}$ concentration above $5 \mu \mathrm{M}$, causing increased paracellular permeability. Similarly, Blais et al. (1999) observed a decrease in the TEER value and a lactate dehydrogenase leakage when Caco-2 cells were exposed to a medium with $10 \mu \mathrm{M} \mathrm{Cd}$.

\subsection{Speciation effects on $\mathrm{Cd}$ and $\mathrm{Zn}$ uptake and transport}

Jumarie et al. (2001) showed that Cd uptake by Caco-2 cells in solutions with increasing chloride concentration was not simply related to the $\mathrm{Cd}^{2+}$ concentration, but that the $\mathrm{CdCl}_{n}{ }^{2-n}$ complexes also contributed to the uptake. They explained the increased uptake by the direct uptake of the complexes via charge-neutral cotransporters. This study highlighted that $\mathrm{CdCl}_{n}{ }^{2-n}$ complexes contribute to almost the same extent to the uptake as the free $\mathrm{Cd}^{2+}$ ion at $\mathrm{pCd}=9.5$. At high $\mathrm{Cd}^{2+}$ concentration $(\mathrm{pCd}=5.5)$, the uptake in the chloride solution was only slightly larger than in the nitrate solution, indicating that there was little contribution of the complexes to the Cd uptake. Similar observations have been made for Cd uptake by plants by Oporto et al. (2009), who 
studied uptake by plants in soil at free $\mathrm{Cd}^{2+}$ activities in the soil solution of $1 \mathrm{nM}, 1 \mu \mathrm{M}$ and 6 $\mu \mathrm{M}$. Cadmium-chloro complexes contributed to the plant uptake at the low $\mathrm{Cd}^{2+}$ concentration, but no contribution was observed at the largest $\mathrm{Cd}^{2+}$ concentration.

Even though direct uptake of the entire complex and the free ion cannot fully be excluded, we hypothesize that the contribution of complexes to the uptake is mainly due to alleviation of diffusion limitations, and this for three reasons. First, the uptake flux was close to the diffusion flux observed for the cell-free well (only filter). Second, the $\mathrm{CdCl}_{n}{ }^{2-n}$ complexes contributed largely to the $\mathrm{Cd}$ uptake at low $\mathrm{Cd}^{2+}$ concentrations but not at high $\mathrm{Cd}^{2+}$, i.e. at low $\mathrm{Cd}^{2+}, \xi$ was close to 1 and at high $\mathrm{Cd}^{2+}, \xi$ was close to zero. The depletion of $\mathrm{Cd}^{2+}$ at the membrane induces dissociation of the labile $\mathrm{CdCl}_{n}{ }^{2-n}$ complexes. This depletion of $\mathrm{Cd}^{2+}$ depends on the ratio of (potential) internalization flux to the (maximal) diffusive flux. At large concentration, the internalization flux saturates, resulting in less depletion of the free ion at the surface. Under such conditions, diffusive transport becomes less important, explaining why there is little contribution of the $\mathrm{CdCl}_{n}{ }^{2-n}$ complexes at the large $\mathrm{Cd}^{2+}$ concentration. Finally, the correlation between the kinetic lability of synthetic complexes and their contribution to the uptake is a strong indication that complexes contribute to uptake because they enhance the diffusion flux (see below).

Also in the solutions with synthetic ligands, the complexes contributed to $\mathrm{Cd}$ and $\mathrm{Zn}$ uptake. In solutions with constant free ion concentration and constant total Cd concentration, the intake flux (based on metal recovered in the cells) increased as the dissociation rate of the complexes and the DGT measured diffusion flux increased (Figure 6 and Table 3). When the total uptake flux (intake + transport to basolateral side) was considered, there was little difference between the complexes of different dissociation rate, and the metals were mainly recovered in the basolateral compartment. We hypothesize that this was mainly transport via a paracellular route (through the 
cell pore junctions). The value of $P_{\text {para }}$ was circa $4 \times 10^{-6} \mathrm{~cm} / \mathrm{s}$. This is in good agreement with paracellular permeabilities reported by Saitoh et al. (2004).

\subsection{Diffusion flux calculations and comparison with (specific) uptake flux}

The correlation between the DGT-measured diffusion fluxes and the intake fluxes (Figure 6) strongly suggest that the specific uptake by the Caco-2 cells is limited by diffusion of the free ion to the uptake sites at the cells surface. Therefore, a more quantitative analysis was carried out by comparing the observed intake fluxes with estimated diffusion flux assuming a near-zero free ion concentration at the uptake site (limiting diffusion flux).

In solutions without complexes, the planar limiting diffusion flux, $F_{\text {diff }}$, corresponds to:

$$
F_{\text {diff }}=\frac{D}{\delta} \cdot\left[\mathrm{M}^{2+}\right]
$$

where $D$ is the diffusion coefficient (circa $8 \times 10^{-6} \mathrm{~cm}^{2} / \mathrm{s}$ at $37^{\circ} \mathrm{C}$ for $\mathrm{Cd}$ and $\mathrm{Zn}$ ) and $\delta$ is the diffusion layer thickness. In the solutions without complexes, the observed $P$ (ratio of uptake flux to metal concentration) was around $4 \times 10^{-5} \mathrm{~cm} / \mathrm{s}$, suggesting a diffusion layer thickness around 2 $\mathrm{mm}$ if uptake was indeed diffusion limited. This value is in good agreement with diffusion layer thickness estimated by Karlsson and Artursson (1991). Based on the observed permeability of 3.6 $\times 10^{-5} \mathrm{~cm} / \mathrm{s}$ for a highly permeable hydrophobic drug (testosterone) in absence of agitation, they estimated a diffusion layer thickness of $1.54 \mathrm{~mm}$. Though unstirred water layers are probably not that large in the human intestine, the mucus layer constitutes a diffusion barrier that is likely of similar magnitude (Avdeef and Tam, 2010).

In solutions with complexes, the diffusion flux can be estimated based on reaction layer concept (Koutecký and Koryta, 1961; Degryse et al., 2006a): 
$F_{\text {diff }}=\frac{D}{\mu} \cdot\left[\mathrm{M}^{2+}\right]$ with $\mu=\sqrt{\frac{D}{k_{\mathrm{d}}} \cdot \frac{\left[\mathrm{M}^{2+}\right]}{[\mathrm{ML}]}}$

where $\mu$ is the reaction layer thickness and $k_{\mathrm{d}}$ the dissociation rate constant of the complex. Because of the buffering by the complexes, the layer over which depletion of the free ion occurs is smaller in presence than in absence of complexes. This reaction layer decreases - and the diffusion flux increases - as the dissociation rate $\left(k_{\mathrm{d}}\right)$ or the concentration of the complexes (relative to free ion concentration; $[\mathrm{ML}] /\left[\mathrm{M}^{2+}\right]$ ) increases. The observed permeabilities (based on $\mathrm{Cd}$ in the cells) agreed reasonably well with those estimated assuming that the intake flux equals the diffusion flux (Table 3), also suggesting that the uptake of cadmium by the Caco-2 cells is limited by diffusion at low free $\mathrm{Cd}^{2+}$ activities.

\subsection{Conditions under which complexes contribute}

The importance of the diffusion barrier is well recognized for the absorption of hydrophobic drugs. Resistance models have been used to model the permeability, where transcellular and paracellular routes of transport through the cell membrane are parallel pathways, in series with the transport barrier of the aqueous boundary layer (ABL) (e.g. Avdeef and Tam, 2010). Here, we use a similar resistance model

$$
P=P_{\text {trans }}+P_{\text {para }}
$$

where $P_{\text {trans }}$ and $P_{\text {para }}$ represent the permeabilities for transcellular and paracellular uptake, respectively. For the paracellular pathway, the transport barrier of the ABL can be ignored, since $P_{\text {para }}$ (around $4 \times 10^{-6} \mathrm{~cm} / \mathrm{s}$ ) is much smaller than the permeability of the ABL (corresponding to $D / \delta$; in the order of $4 \times 10^{-5} \mathrm{~cm} / \mathrm{s}$ ). For the transcellular pathway, the ABL transport barrier cannot be ignored, so we use following equation: 


$$
P_{\text {trans }}=\frac{1}{\frac{1}{P_{\mathrm{ABL}}}+\frac{1}{P_{\mathrm{int}}}}
$$

where $P_{\mathrm{ABL}}$ represents the transport through the aqueous boundary layer and $P_{\text {int }}$ the internalization flux across the cellular membrane. The slowest process determines the rate of the transcellular uptake. If $P_{\mathrm{ABL}}$ is smaller than $P_{\mathrm{int}}$, the uptake is diffusive controlled. If $P_{\mathrm{ABL}}$ is larger than $P_{\text {int }}$, the uptake is membrane controlled.

This equation is somewhat different from the one proposed by Avdeef and Tam (2010), as we have to take into account that only the free ion is transported by specific uptake via the transcellular pathway, while all species can move by passive transport via the paracellular pathway.

The value of $P_{\mathrm{ABL}}$, which represents the diffusion of the free ion through the aqueous boundary layer, can be estimated as the ratio of the estimated ionic diffusion flux (Eq. 5 or 6 ) and the total metal concentration. In media without metal-complexing ligands, $P_{\mathrm{ABL}}$ corresponds to $D / \delta$. In buffered media, $P_{\mathrm{ABL}}$ is calculated as $D / \mu \times\left[\mathrm{M}^{2+}\right] /\left[\mathrm{M}_{\mathrm{tot}}\right]$.

The value of $P_{\text {int }}$ represents the specific ion uptake by the cell, and is therefore related to the degree of buffering as follows:

$$
P_{\text {int }}=\frac{F_{\text {int }}}{\left[\mathrm{M}_{\mathrm{tot}}\right]}=P_{\text {int, free }} \frac{\left[\mathrm{M}^{2+}\right]}{\left[\mathrm{M}_{\mathrm{tot}}\right]}
$$

where $P_{\text {int, free }}$ represents the ratio of internalization flux to free ion concentration at the membrane surface. Given that the specific uptake is likely free ion specific, $P_{\text {int,free }}$ is assumed to be independent of metal speciation, whereas $P_{\text {int }}$ depends on the free ion fraction. At large metal 
concentrations, we found evidence that the uptake saturates and is membrane controlled $\left(P_{\text {int }}<P_{\mathrm{ABL}}\right.$; internalization control). A decrease in $P$ was observed and there was little contribution of the Cd-chloro complexes. Therefore, at large concentration, we can estimate $P_{\text {int(free) }}$ from the observed uptake. However, at small concentrations, all evidence pointed to diffusion limitation (i.e. $P_{\mathrm{ABL}}<<P_{\mathrm{int}}$ ). Complexes contribute to the uptake, the degree of this contribution increases with increasing dissociation rate of the complexes, and the observed uptake flux corresponds well with the estimated limiting diffusion flux. As a result, we cannot estimate $P_{\text {int(free) }}$ at the low concentrations, since the observed permeability (for the specific uptake into the cells) approaches $P_{\mathrm{ABL}}$ under these conditions. However, we can infer that $P_{\text {int,free }}$ $>10^{-3} \mathrm{~cm} / \mathrm{s}$ at the low concentrations, since otherwise, the uptake would have been internalization controlled in the solutions with large concentration of complexes and no contribution of the complexes would have been observed.

Table 5 summarizes predictions for different scenarios. In the unbuffered solutions, the specific uptake shifts from transport limited $\left(P_{\mathrm{ABL}}<P_{\text {int }}\right)$ at low concentrations to internalization limited $\left(P_{\mathrm{ABL}}>P_{\mathrm{int}}\right)$ at high concentrations $(10 \mu \mathrm{M})$. This results in lower contribution of labile complexes at larger activities (first 3 lines for buffered scenarios in Table 5) as was observed for the Cdchloro complexes. Furthermore, the table illustrates the effect of dissociation rate and concentration of complexes on the contribution of complexes to the specific uptake at low free ion activities.

Since $P_{\text {para }}$ is estimated to be around $4 \times 10^{-6} \mathrm{~cm} / \mathrm{s}$, the paracellular pathway is only expected to have a large contribution (more than $30 \%$ of overall transport) if $P_{\text {trans }}$ is less than $10^{-5} \mathrm{~cm} / \mathrm{s}$ (Eq. 7). Thus a large contribution of this pathway is only expected at high $\mathrm{Cd}$ concentrations where the internalization saturates and uptake becomes membrane limited or at high degree of buffering 
(large complex to free ion concentration) especially with slowly dissociating complexes (cf. Table 5).

\section{Conclusion}

The Free Ion Activity Model (FIAM) predicts that Cd uptake is identical for solutions with the same free ion concentration and inorganic composition. Here, an increased uptake of $\mathrm{Cd}$ in the presence of complexes at low free $\mathrm{Cd}^{2+}$ concentration was observed. The contribution of the complexes to the metal uptake was less pronounced at higher free ion concentrations. Observed uptake of $\mathrm{Cd}$ in the cells agreed well with predicted uptake if diffusion of the free ion to the cell surface was assumed to be the rate-limiting step. These results suggest that the uptake of Cd from solution by intestinal cells is limited by diffusion at low metal concentrations. The intestinal diffusion barrier in vivo is likely similar or even larger than in our assays, and Cd uptake in the gastrointestinal tract is therefore expected to be also diffusion-limited.

\section{Acknowledgments}

This research was funded by the Onderzoeksfonds K.U.Leuven under the project number OT/08/020. F. Degryse thanks the Fund for Scientific Research (F.W.O.-Vlaanderen) for a postdoctoral fellowship and L. Verheyen thanks the Institute for the Promotion of Innovation through Science and Technology in Flanders (IWT-Vlaanderen). We thank Marisa Geens (Division Animal-nutrition-quality) for culturing the Caco-2 cells. 


\section{References}

Artursson P, Palm K, Luthman K. Caco-2 monolayers in experimental and theoretical predictions of drug transport. Adv. drug Delivery Rev 2001; 46: 27-43.

Avdeef A, Tam KY. How well can the Caco-2/Madin-Darby canine kidney models predict effective human jejunal permeability? J Med Chem 2010; 53: 3566-3584.

Blais A, Lecoeur S, Milhaud G, Tomé D, Kolf-Clauw M. Cadmium uptake and transepithelial transport in control and long-term exposed Caco-2 cells: The role of Metallothionein. Toxicol Appl Pharmacol 1999; 160: 76-85.

Degryse F, Smolders E, Merckx R. Labile Cd complexes increase availability to plants. Environ Sci Technol 2006a; 40: 830-836.

Degryse F, Smolders E, Parker DR. Metal complexes increase uptake of $\mathrm{Zn}$ and $\mathrm{Cu}$ by plants: implications for uptake and deficiency studies in chelator-buffered solutions. Plant Soil 2006b; 289: 171-185.

Duizer E, Gilde AJ, Versantvoort CHM, Groten JP. Effects of cadmium chloride on the paracellular barrier function of intestinal epithelial cell lines. Toxicol Appl Pharm 1999;155: 117-126.

Elisma F, Jumarie C. Evidence for cadmium uptake through Nramp2: Metal speciation studies with Caco2 cells. Biochem Biophys Res Commun 2001; 285: 662-668.

Fogh J, Fogh JM, Orfeo T. One hundred and twenty seven cultured human tumor cell lines producing tumors in nude mice. J Natl Cancer Inst 1977; 59: 221-226.

Han O, Failla ML, Hill AD, Morris ER, Smith JCJr. Inositol phosphates inhibit uptake and transport of iron and zinc by a human intestinal cell line. J Nutr 1994; 124: 580-587.

Helmke PA, Lampert JK, Li Y. Indigenous levels of cation activities in soil solutions and natural waters by Donnan membrane equilibrium and atomic absorption analysis. Anal Chem 1999; 1-28. 
Hidalgo IJ, Raub TJ, Borchardt RT. Characterization of the human colon cell line (Caco 2) as a model system for intestinal epithelial permeability. Gastroenterology 1989; 96: 736-749.

Hotz C. Evidence for the usefulness of in vitro dialyzability, Caco-2 cell models, animal models, and algorithms to predict zinc bioavailability in humans. Int J Vitam Nutr Res 2005; 75: 423-435.

Ingels F, Deferme S, Destexhe E, Oth M, Van den Mooter G, Augustijns P. Simulated intestinal fluid as transport medium in the Caco-2 cell culture model. Int J Pharm 2002; 183-192.

Irvine JD, Takahashi L, Lockhart K, Cheong J, Tolan JW, Selick HE, Grove JR. MDCK (Madin-Darby canine kidney) cells: A tool for membrane permeability screening. J Pharm Sci 1999; 88: 28-33.

Jumarie C, Campbell PGC, Berteloot A, Houde M, Denizeau F. Caco-2 cell line used as an in vitro model to study cadmium accumulation in intestinal epithelial cells. J Membrane biol 1997;158: 31-48.

Jumarie C, Campbell PGC, Houde M, Denizeau F. Evidence for an intracellular barrier to cadmium transport through Caco-2 cell monolayers. J Cell Physiol 1999;180: 285-297.

JumarieC, Fortin C, Houde M, Campbell PGC, Denizeau F. Cadmium uptake by Caco-2 cells: Effects of Cd complexation by chloride, glutathione, and phytochelatins. Toxicol Appl Pharm 2001; 170: 2938.

Karlsson J, Artursson P. A method for the determination of cellular permeability coefficients and aqueous boundary-layer thickness in monolayers of intestinal epithelial (Caco-2) cells grown in permeable filter chambers. International journal of pharmaceutics 1999; 71: 55-64.

Koutecký J, Koryta J. The general theory of polarographic kinetic currents. Electrochim Acta 1961; 3: 318-339.

Lönnerdal B, Cederblad Å, Davidsson L, Sandström B. The effect of individual components of soy formula and cow's milk formula on zinc bioavailability. Am J Clin Nutr 1984; 40: 1064-1070. 
Morel FMM. Principles of aquatic chemistry. Wiley-interscience, New York; 1983.

Navarro P, Aspe T, Seiquer I. Zinc transport in Caco-2 cells and zinc balance in rats: Influence of the heat treatment of a casein-glucose-fructose mixture. J Agr Food Chem 2000; 48: 3589-3596.

Nolan AL, Lombi E, McLaughlin J. Metal bioaccumulation and toxicity in soils-Why bother with speciation? Aus J Chem 2003; 56: 77-91.

Oporto C, Smolders E, Degryse F, Verheyen L, Vandecasteele C. DGT-measured fluxes explain the chloride-enhanced cadmium uptake by plants at low but not at high Cd supply. Plant Soil 2009; 318: $127-135$.

Parker DR, Norvell WA, Chaney RL. GEOCHEM-PC a chemical speciation program for IBM and compatible personal computers, in Loeppert, R.H., Schwab, A.P., Goldberg, S., Chemical equilibrium and reaction models. Eds., SSSA special publication. 42: Madison, WI; 1995.

Pigman, E.A., Blanchard, J., Laird, H.E., 1997. A study of cadmium transport pathways using the Caco-2 cell model. Toxicol. Appl. Pharmacol. 142, 243-247.

Reeves PG, Briske-Anderson M, Johnson L. Pre-treatement of Caco-2 cells with zinc during the differentiation phase alters the kinetics of zinc uptake and transport. J Nutr Biochem 2001a 12, :674-684.

Reeves PG, Chaney RL. Mineral status of female rats affects the absorption and organ distribution of dietary cadmium derived from edible sunflower kernels (Heliarthus annuus L.). Env Research 2001b. 85: 215-225.

Seiquer I, Valverde A, Delgado-Andrade C, Navarro MP. Influence of heat treatment of casein in presence of reducing sugars on $\mathrm{Zn}$ solubility and $\mathrm{Zn}$ uptake by Caco-2 cells after in vitro digestion. Journal of Physiology and Biochemistry 2000; 56: 237-246. 
Rossi A, Poverini R, DiLullo G, Modesti A, Scarino ML. Heavy metal toxicity following apical and basolateral exposure in the human intestinal cell line Caco-2. Toxicol Vitro 1996; 10: 27-31.

Ryan JA, Scheckel KG, Berti WR, Brown SL, Casteel SW, Chaney RL, Hallfrisch J, Doolan M, Grevatt P, Maddaloni M, Mosby D. Reducing children's risk from lead in soil. Environ Sci Technol 2004; 38: 18A-24A.

Saitoh R, Sugano K, Takata N, Tachibana T, Higashida A, Nabuchi Y, Aso Yoshinori. Radius of tight junctions in Caco-2 monolayers improves the prediction of the dose fraction of hydrophilic drugs absorbed by humans. Pharm Res 2004; 21: 749-755.

Simon-Hettich B. International programme in chemical safety (IPCS): Environmental Health Criteria 134 cadmium. Geneva: HO; 1992. Available from http://www.inchem.org/documents/ehc/ehc/ehc134.htm ; 2012.

Turnlund J R, King J C, Keyes WR, Gong B, Michel MC. A stable isotope study of zinc absorption in young men: effects of phytate and $\alpha$-cellulose. Am J Clin Nutr 1982; 40: 1071-1077.

Vahter M, Berglund M, Nermell B, Akesson A. Bioavailability of cadmium form shellfisch and mixed diet in women. Toxicol Appl Pharmacol 1996; 136: 332-341.

Zhang H, Davison W. Direct in situ measurements of labile inorganic and organically bound metal species in synthetic solutions and natural waters using diffusive gradients in thin films. Anal Chem 2000; 72: $4447-4457$. 
Table 1: The permeability $P$ for $\mathrm{Cd}$ and $\mathrm{Zn}$ of the Caco-2 cells (calculated based on the loss of metal from the apical compartment during the first hour) and the fraction of $\mathrm{Cd}$ or $\mathrm{Zn}$ taken up that is transported to the basolateral side (BL) after 1 hour, for different metal concentrations in the apical solution. Each line represents a different composition in the apical medium. The permeability gives the ratio of the uptake per unit surface normalized to the total metal concentration in the apical medium (standard error between brackets, $n=2$ ). The solutions contained no metal-complexing ligands.

\begin{tabular}{|c|c|c|c|c|c|c|c|}
\hline \multicolumn{4}{|c|}{ cadmium } & \multicolumn{4}{|c|}{ zinc } \\
\hline $\mathrm{Cd}_{\text {tot }}$ & $\mathrm{pCd}$ & $P$ & Fraction to & $\mathrm{Zn}_{\text {tot }}$ & $\mathrm{pZn}$ & $P$ & Fraction to \\
\hline$(\mu \mathrm{M})$ & & $\left(10^{-6} \mathrm{~cm} / \mathrm{s}\right)$ & BL & $(\mu \mathrm{M})$ & & $\left(10^{-6} \mathrm{~cm} / \mathrm{s}\right)$ & BL \\
\hline Carrier-free & & $32.5(2.2)$ & 0.02 & Carri & & $56.4(2.0)$ & 0.03 \\
\hline 0.001 & 9.5 & 35.2 (1.9) & $<0.01$ & 0.01 & 8.6 & $53.3(3.5)$ & 0.02 \\
\hline 0.1 & 7.5 & $44.7(2.3)$ & $<0.01$ & 1 & 6.6 & $50.0(4.6)$ & $<0.01$ \\
\hline 10 & 5.5 & $25.9(3.0)$ & 0.33 & 100 & 4.6 & $15.1(2.0)$ & 0.51 \\
\hline 1 & 6.5 & $40.7(0.9)$ & 0.03 & \multicolumn{2}{|c|}{ Carrier-free } & $59.5(2.0)$ & $<0.01$ \\
\hline 10 & 5.5 & $24.1(1.9)$ & 0.12 & \multicolumn{2}{|c|}{ Carrier-free } & $55.2(4.1)$ & $<0.01$ \\
\hline 30 & 5.1 & $15.6(0.5)$ & 0.24 & \multicolumn{2}{|c|}{ Carrier-free } & $37.2(0.9)$ & $<0.01$ \\
\hline Carrier-free & & $26.4(1.2)$ & 0.22 & 100 & 4.6 & $11.1(1.0)$ & 0.27 \\
\hline
\end{tabular}


Table 2: The theoretical species distribution of $\mathrm{Cd}$ and $\mathrm{Zn}$ (as \% of total dissolved) in the test solutions with $137 \mathrm{mM} \mathrm{NaCl}$ or $137 \mathrm{mM} \mathrm{NaNO}_{3}$ (calculated by GEOCHEM-PC, Parker et al., 1995). Only the most important complexes (>3\%) are given.

\begin{tabular}{|c|c|c|c|}
\hline \multicolumn{2}{|c|}{ cadmium } & \multicolumn{2}{|c|}{ zinc } \\
\hline $\mathrm{NaCl}$ & $\mathrm{NaNO}_{3}$ & $\mathrm{NaCl}$ & $\mathrm{NaNO}_{3}$ \\
\hline $15 \%$ free & $88 \%$ free & $81 \%$ free & $81 \%$ free \\
\hline $84 \% \mathrm{Cl}^{-}$complex & $9 \% \mathrm{NO}_{3}{ }^{-}$complex & $9 \% \mathrm{Cl}^{-}$complex & $10 \% \mathrm{NO}_{3}{ }^{-}$complex \\
\hline & & $7 \% \mathrm{OH}^{-}$complex & $7 \% \mathrm{OH}^{-}$complex \\
\hline
\end{tabular}


Table 3: The permeability based on Cd recovered in the basolateral compartment $\left(P_{\text {baso }}\right)$ and based on Cd recovered in the cells $\left(P_{\text {cell }}\right)$ after 4 hours of exposure to apical test solutions with 1 $\mathrm{nM} \mathrm{Cd}^{2+}$ and $1 \mu \mathrm{M}$ of $\mathrm{Cd}$ complexes with synthetic ligands, varying in dissociation rate. The value of $P_{\text {cell }}$ was predicted assuming that the specific uptake of $\mathrm{Cd}$ by the cells was limited by diffusion of the free $\mathrm{Cd}^{2+}$ ion to the cell surface (Eq. 6). The contribution of the complexes to the specific uptake, relative to that of the free ion, is expressed by $\xi$ (Eq. $4 ; \xi=1$ : complexes contribute to the same extent as the free ion; $\xi=0$ : no contribution of the complex). (Standard errors between brackets)

\begin{tabular}{|c|c|c|c|c|c|}
\hline & \multirow[t]{2}{*}{$k_{\mathrm{d}}(1 / \mathrm{s})^{\mathrm{a}}$} & \multirow[t]{2}{*}{$P_{\text {baso }}\left(10^{-6} \mathrm{~cm} / \mathrm{s}\right)$} & \multicolumn{2}{|c|}{$P_{\text {cell }}\left(10^{-6} \mathrm{~cm} / \mathrm{s}\right)$} & \multirow[t]{2}{*}{$\xi$} \\
\hline & & & observed & predicted & \\
\hline HEDTA & $1.5 \times 10^{-3}$ & $3.88(0.01)$ & $1.86(0.005)$ & 3.46 & 0.06 \\
\hline EDTA & $1.8 \times 10^{-4}$ & $4.27(0.49)$ & $0.74(0.05)$ & 1.20 & 0.02 \\
\hline CDTA & $9.9 \times 10^{-6}$ & $4.02(0.94)$ & $0.45(0.14)$ & 0.28 & 0.01 \\
\hline
\end{tabular}

${ }^{\mathrm{a}} k_{\mathrm{d}}$, dissocation rate constant from Degryse et al. (2006a) 
Table 4: The uptake flux of $\mathrm{Cd}$ and $\mathrm{Zn}$ (standard error between brackets) from apical solutions with identical free $\mathrm{Cd}^{2+}$ and $\mathrm{Zn}^{2+}$ concentration $\left(\mathrm{pCd} 8.7, \mathrm{Cd}^{2+}\right.$ concentration $1.8 \mathrm{nM}$; pZn 7.8, $\mathrm{Zn}^{2+}$ concentration $53 \mathrm{nM}$ ) and total to free ion concentration as specified in the table. The solutions were obtained by equilibrating a metal-loaded resin with the basal medium containing no ligand or metal-complexing ligands in concentrations as specified. The uptake flux was calculated from the amount of metal recovered in the cells and in the basolateral compartment, after a 4-hours uptake period. The larger uptake in presence of complexes indicates that the free ion activity model is not valid.

\begin{tabular}{|c|c|c|c|c|c|}
\hline \multicolumn{2}{|l|}{ Ligand } & \multicolumn{2}{|c|}{ cadmium } & \multicolumn{2}{|c|}{ zinc } \\
\hline Type & $\mathrm{c}$ & {$\left[\mathrm{Cd}_{\mathrm{tot}}\right] /\left[\mathrm{Cd}^{2+}\right]$} & $F$ & {$\left[\mathrm{Zn}_{\mathrm{tot}}\right] /\left[\mathrm{Zn}^{2+}\right]$} & $F$ \\
\hline & $(\mu \mathrm{M})$ & & $\left(\mathrm{pmol} / \mathrm{cm}^{2} / \mathrm{h}\right)$ & & $\left(\mathrm{pmol} / \mathrm{cm}^{2} / \mathrm{h}\right)$ \\
\hline None & - & 1.1 & $0.65(0.06)$ & 1.3 & $7.6(0.6)$ \\
\hline NTA & 10 & 7.7 & $3.87(0.16)$ & 53.5 & $104.5(16.5)$ \\
\hline HEDTA & 0.2 & 5.9 & $2.40(0.17)$ & 5.3 & $20.6(1.8)$ \\
\hline EDTA & 1 & 9.0 & $4.78(0.25)$ & 17.3 & 47.7 (7.2) \\
\hline CDTA & 1 & 15.8 & $3.21(0.23)$ & 20.0 & $27.4(1.4)$ \\
\hline
\end{tabular}


Table 5: Predicted permeabilities and fluxes for the transcellular pathway ( $P_{\text {trans }}$ and $\left.F_{\text {trans }}\right)$ using a resistance model, with transport through the aqueous boundary layer $\left(P_{\mathrm{ABL}}\right)$ and specific uptake by the cell $\left(P_{\text {int }}\right)$ in series. The predicted contribution of the complexes to the specific uptake, relative to that of the free ion, is expressed by $\xi(\xi=1$ : complexes contribute to the same extent as the free ion; $\xi=0$ : no contribution of the complex). The rate-limiting step (transport through the ABL or internalization by the cell) is indicated in bold.

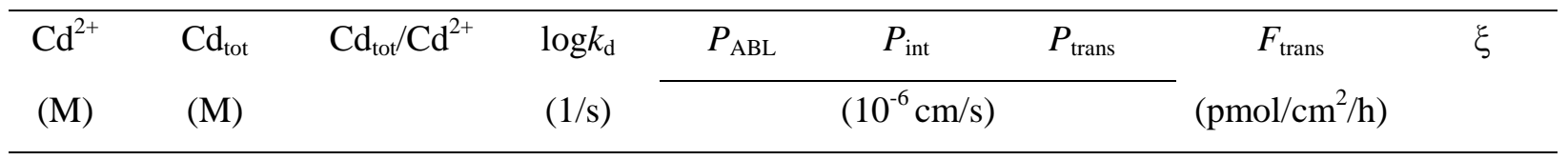

\section{Unbuffered}

$\begin{array}{lllrrrr}10^{-9} & 10^{-9} & 1 & \mathbf{3 5} & 3000^{\text {a }} & 35 & 0.12 \\ 10^{-7} & 10^{-7} & 1 & \mathbf{3 5} & 3000^{\text {a }} & 35 & 12.5 \\ 10^{-5} & 10^{-5} & 1 & 35 & \mathbf{2 0} & 13 & 458\end{array}$

\section{Buffered}

\begin{tabular}{|c|c|c|c|c|c|c|c|c|}
\hline $10^{-9}$ & $10^{-8}$ & 10 & $>-2$ & 35 & 300 & 31 & 1.1 & 0.90 \\
\hline $10^{-7}$ & $10^{-6}$ & $"$ & $"$ & 35 & 300 & 31 & 113 & 0.90 \\
\hline $10^{-5}$ & $10^{-4}$ & $"$ & $"$ & 35 & 2 & 1.9 & 681 & 0.05 \\
\hline $10^{-9}$ & $10^{-8}$ & 10 & -3 & 27 & 300 & 25 & 0.89 & 0.68 \\
\hline$"$ & $"$ & $"$ & -4 & 8.5 & 300 & 8.3 & 0.30 & 0.15 \\
\hline$"$ & $"$ & $"$ & -5 & 3.5 & 300 & 2.7 & 0.10 & 0.00 \\
\hline $10^{-9}$ & $10^{-6}$ & 1000 & -3 & 2.8 & 3.0 & 1.5 & 5.2 & 0.04 \\
\hline$"$ & $"$ & $"$ & -4 & 0.9 & 3.0 & 0.7 & 2.5 & 0.02 \\
\hline$"$ & $"$ & $"$ & -5 & 0.3 & 3.0 & 0.3 & 0.93 & 0.01 \\
\hline
\end{tabular}

$P_{\mathrm{ABL}}$ : calculated as ratio of the estimated diffusion flux of $\mathrm{Cd}^{2+}$ (Eq. 5/6) and the total metal concentration. $P_{\text {int }}$ : estimated for unbuffered solutions $\left(P_{\text {int,free}}\right)$ from observed uptake; calculated for buffered solutions using Eq. 9.

$P_{\text {trans }}:$ from serial model: $1 / P_{\text {trans }}=1 / P_{\mathrm{ABL}}+1 / P_{\text {int }}($ Eq. 8$)$ 
${ }^{\text {a }} P_{\text {int,free }}$ uncertain at low activities, estimated to be larger than $10^{-3} \mathrm{~cm} / \mathrm{s}$; see text 
Figure 1: Schematic representation of the $\mathrm{CaCo}-2$ cells and the uptake processes. Metalcontaining solutions were added at the apical side. The uptake flux was calculated from the loss of metal at the apical side; this flux accounts both for metal accumulating in the cell (intake) and metal transported to the basolateral side. To interpret and model the results, two pathways were distinguished: the transcellular pathway, in which the free metal ion $\left(\mathrm{M}^{2+}\right)$ is taken up in the cells by specific transport, and the paracellular pathway, in which all metal species diffuse through cell pore junctions. The rates for both pathways are expressed using permeabilities $P$ (ratio of flux to concentration). In the transcellular pathway, the diffusion of free ion through the aqueous boundary layer (quantified by $P_{\mathrm{ABL}}$ ) is in series with the internalization across the apical membrane (quantified by $P_{\text {int }}$ ). The slowest process determines the overall rate.

Figure 2: Cross-section of a DGT device. The metals diffuse from the solution through the filter membrane and the diffusion layer towards the resin layer which acts as a zero sink for trace metals.

Figure 3: The total amount of $\mathrm{Cd}$ and $\mathrm{Zn}$ taken up by the Caco-2 (calculated from the loss at the apical side) and the amount transported to the basolateral side as a function of time, in solutions without metal-complexing ligands (137 $\mathrm{mM} \mathrm{NaNO}_{3}$ in basal medium). The metal activities in the apical test solutions were (a) pCd 9.5 and pZn 8.6, or (b) pCd 5.5 and pZn 4.6. The error bars give the standard error of two replicates.

Figure 4: (a) The permeability (uptake flux divided by concentration) and (b) the uptake flux of $\mathrm{Cd}$ and $\mathrm{Zn}$ by the Caco- 2 cells as function of free ion concentration, for solutions without metal complexing ligands. The lines give the observed permeability for the cell-free well (diffusion 
over filter only). Fluxes and permeabilities are based on the data for 1 hour of exposure. Uptake was calculated from the loss of metal at the apical side.

Figure 5: The total amount $\mathrm{Cd}$ or $\mathrm{Zn}$ taken up by the Caco-2 cells (calculated from the loss at the apical side) for solutions with $137 \mathrm{mM} \mathrm{NaCl}$ or $\mathrm{NaNO}_{3}$ as function of time. The total $\mathrm{Cd}$ concentration was 6 times higher in the $\mathrm{NaCl}$ treatment than in the $\mathrm{NaNO}_{3}$ treatment but free ion activities were the same (because of Cd-choro complexation). The uptake of $\mathrm{Cd}$ at 1 hour of exposure was significantly higher $(\mathrm{p}<0.05)$ in the $\mathrm{NaCl}$ treatment compared to the $\mathrm{NaNO}_{3}$ treatment. The $\mathrm{Zn}$ uptake was not significantly different ( $\mathrm{p}>0.05)$ after one hour of exposure. The metal activities in the apical test solutions were (a) pCd 9.5 and pZn 8.6; (b) pCd 7.5 and pZn 6.6; and (c) $\mathrm{pCd} 5.5$ and $\mathrm{pZn}$ 4.6. The error bars give the standard error of two replicates.

Figure 6: The total uptake flux of $\mathrm{Cd}$ after 4 hours of exposure from the apical solution by the Caco- 2 cells and the intake flux (based on Cd in cells) for solutions with $1 \mathrm{nM}$ free $\mathrm{Cd}^{2+}$ and 1 $\mu \mathrm{M} \mathrm{Cd}$ complex (with ligands as indicated in the graph) as a function of the DGT-measured diffusion flux of the solutions. The solid line is the 1:1 line. The error bars give the standard error of two replicates. 


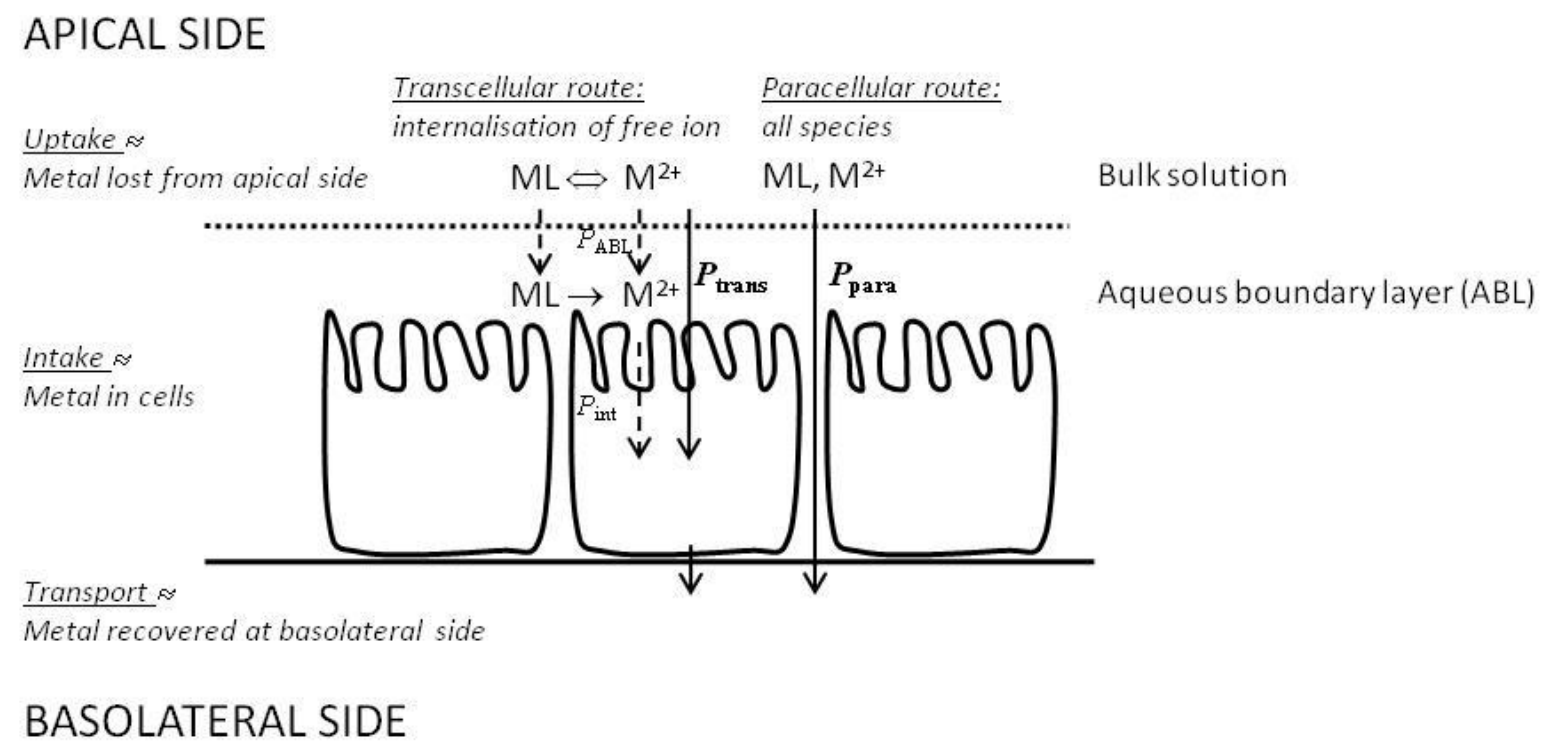

Figure 1 


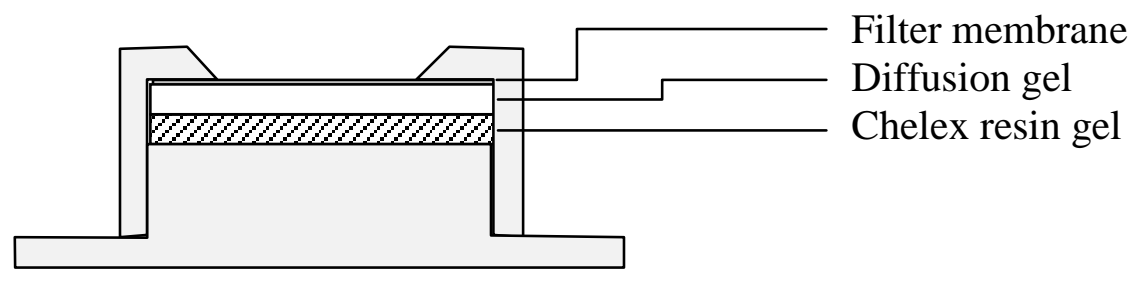

Figure 2 

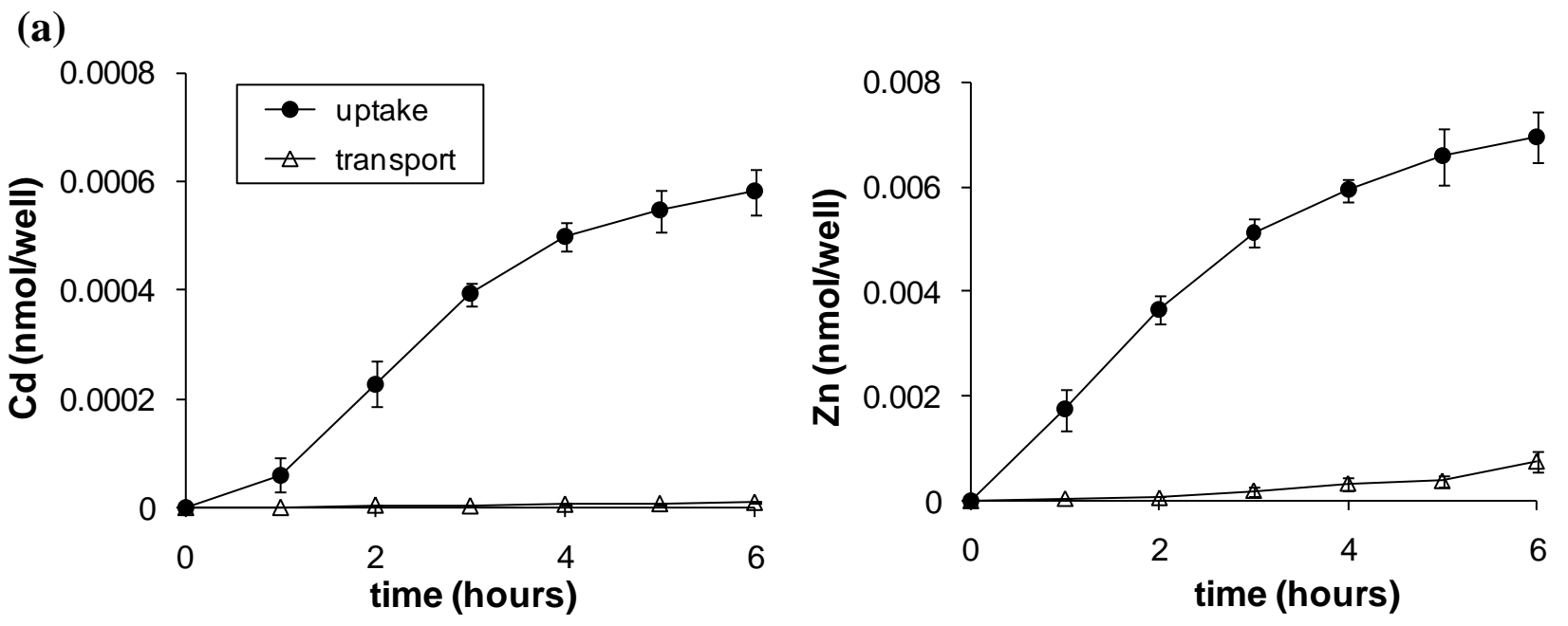

(b)
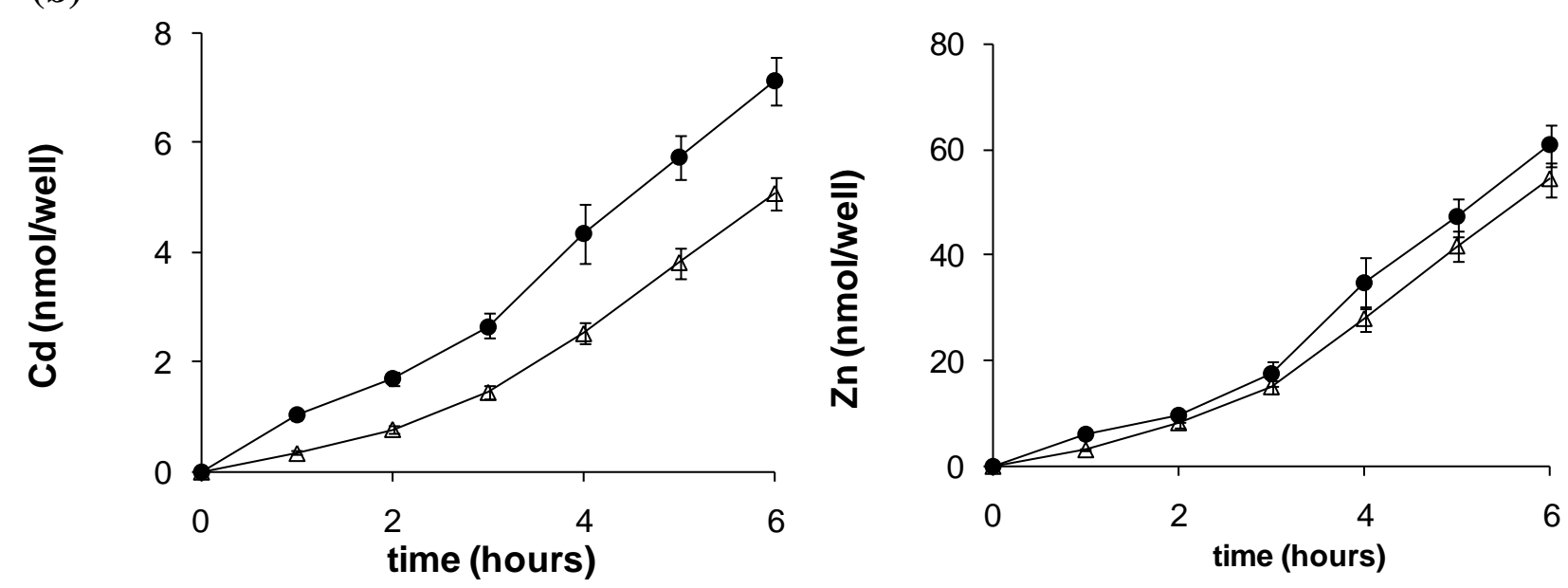

Figure 3 
(a)

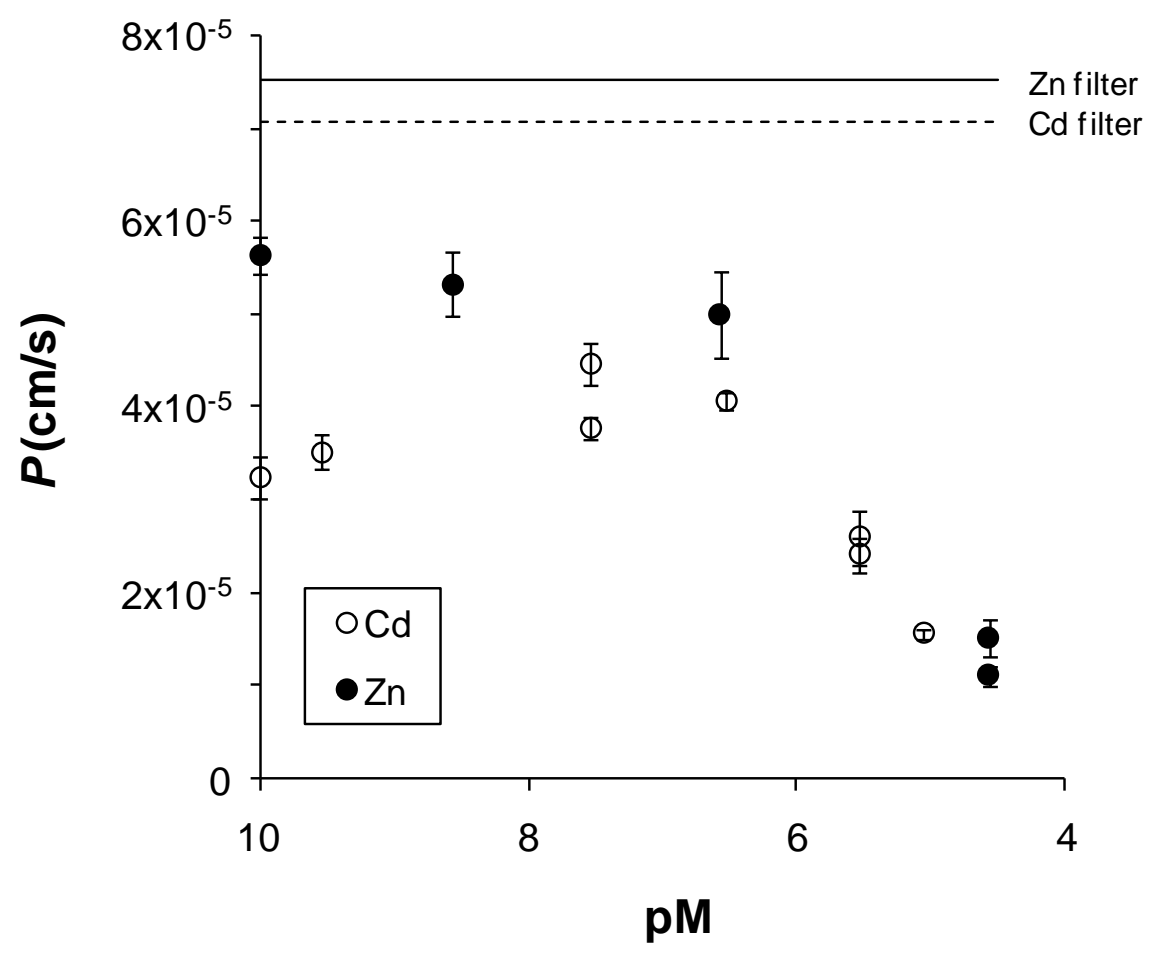

(b)

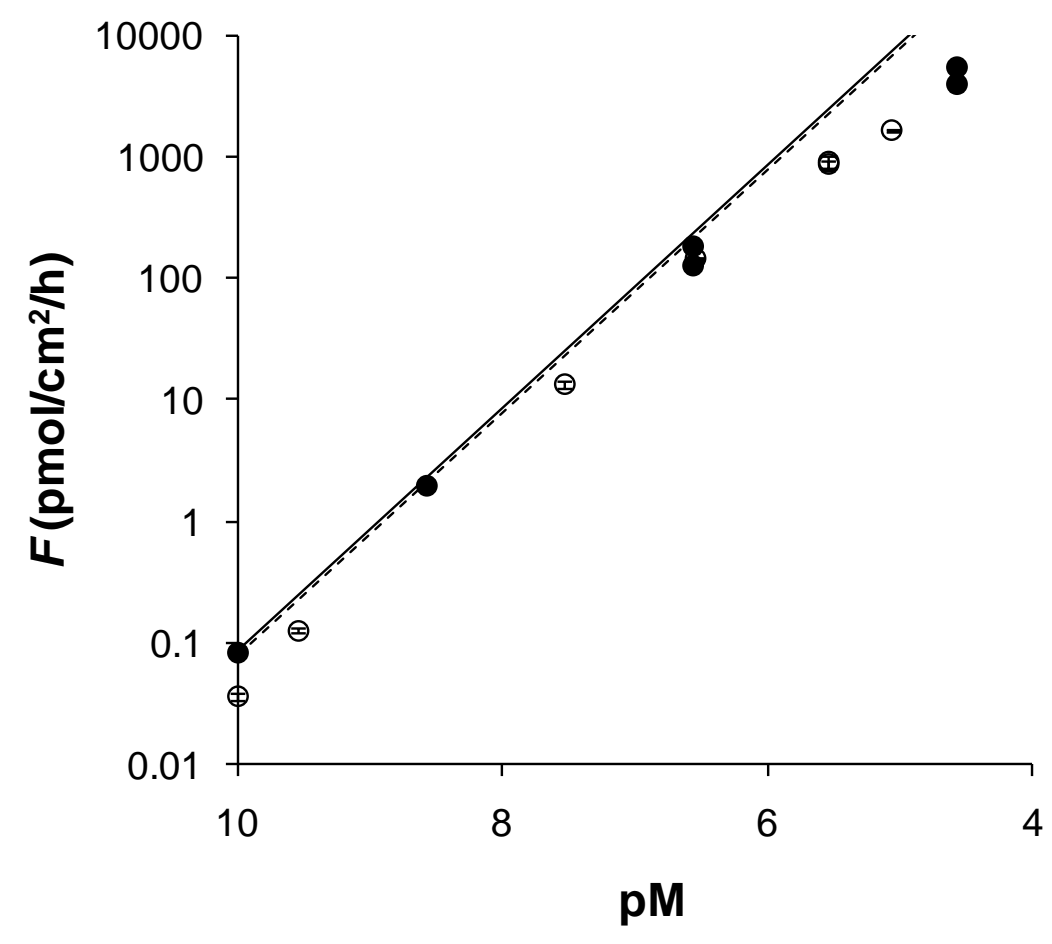

Figure 4 

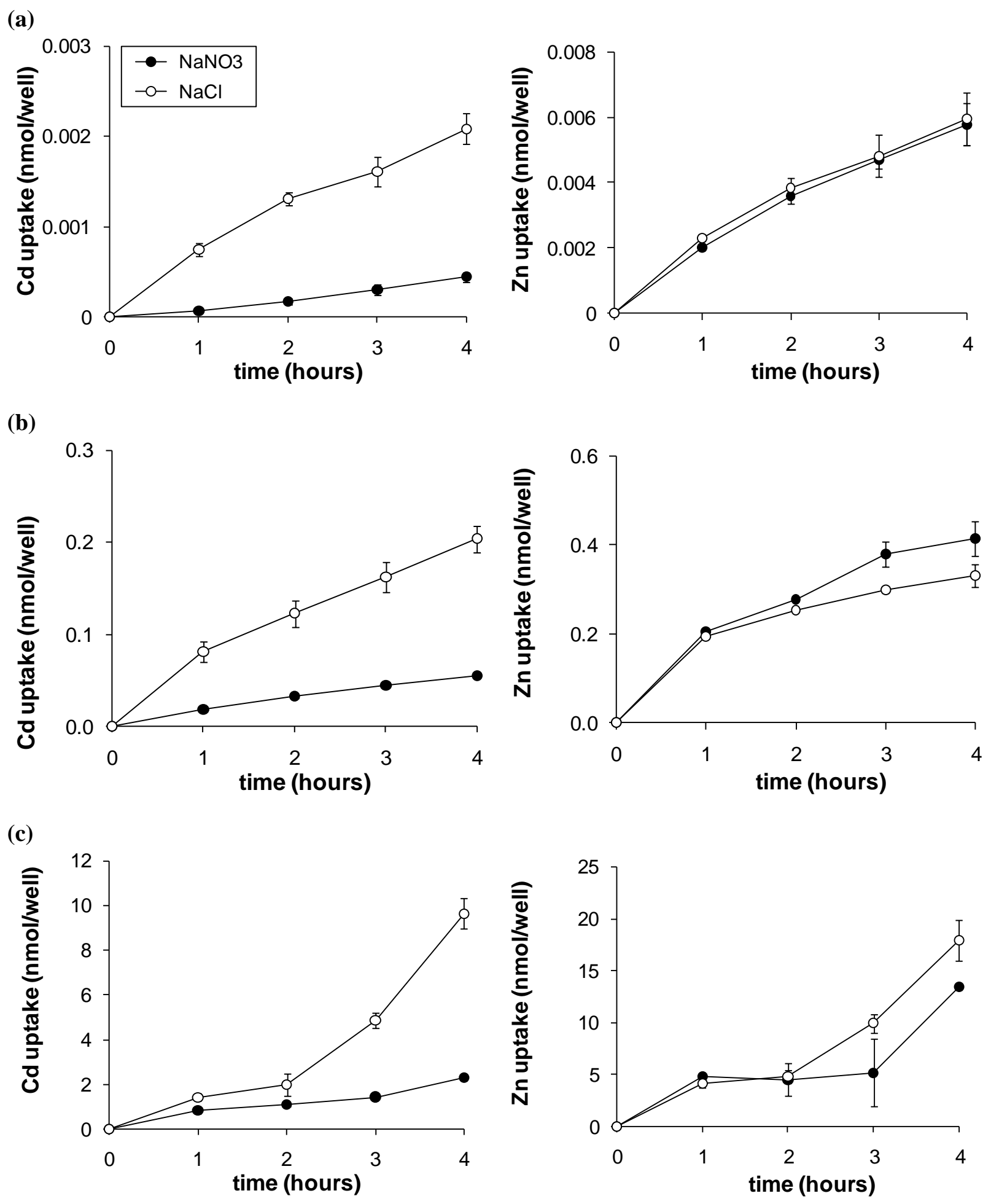

Figure 5 


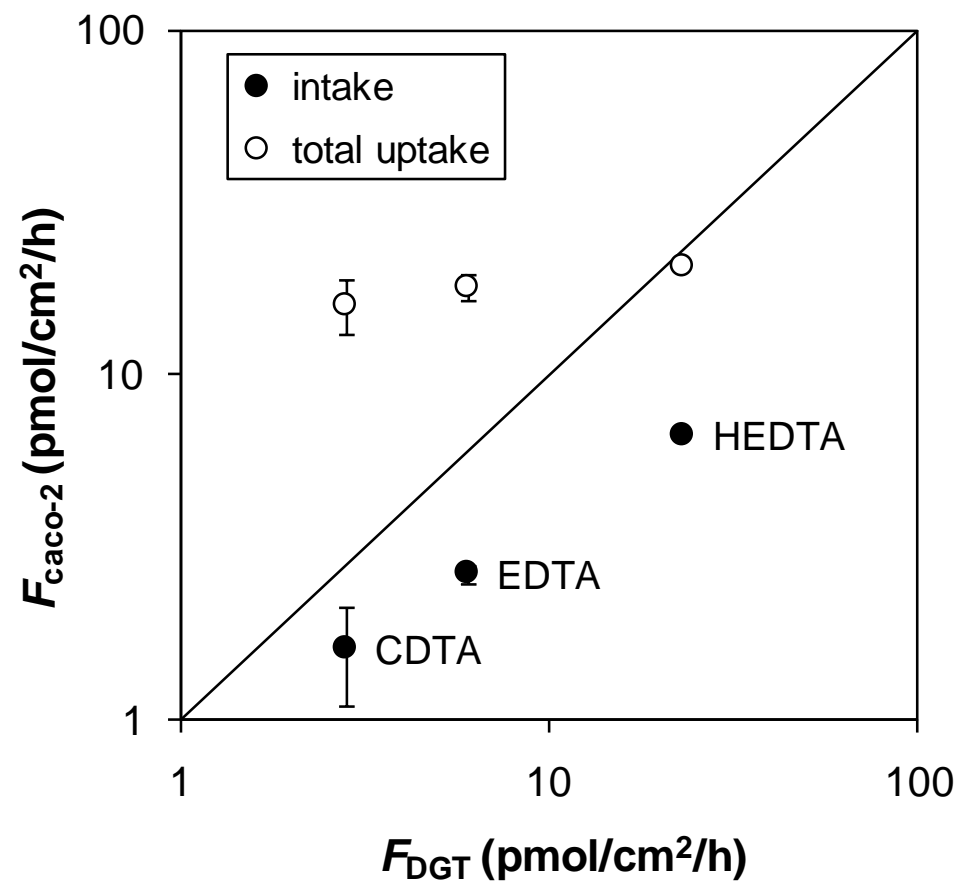

Figure 6 